\title{
The Role of Selected Ecosystem Services in Different Farming Systems in Poland Regarding the Differentiation of Agricultural Land Structure
}

\author{
Lidia Luty $^{1}$ (D), Kamila Musiał ${ }^{2}$ and Monika Zioło ${ }^{1, *(D)}$ \\ 1 Department of Statistics and Social Policy, University of Agriculture in Krakow, al. Mickiewicza 21, \\ 31-120 Krakow, Poland; lidia.luty@urk.edu.pl \\ 2 Department of Production Systems and Environment, National Research Institute of Animal Production, \\ ul. Krakowska 1, 32-083 Balice, Poland; kamila.musial@iz.edu.pl \\ * Correspondence: monika.ziolo@urk.edu.pl
}

Citation: Luty, L.; Musiał, K.; Zioło, M. The Role of Selected Ecosystem Services in Different Farming Systems in Poland Regarding the Differentiation of Agricultural Land Structure. Sustainability 2021, 13, 6673. https://doi.org/10.3390/su13126673

Academic Editors: Damian Chmura and Gabriela Woźniak

Received: 7 April 2021

Accepted: 8 June 2021

Published: 11 June 2021

Publisher's Note: MDPI stays neutral with regard to jurisdictional claims in published maps and institutional affiliations.

Copyright: (c) 2021 by the authors. Licensee MDPI, Basel, Switzerland. This article is an open access article distributed under the terms and conditions of the Creative Commons Attribution (CC BY) license (https:/ / creativecommons.org/licenses/by/ $4.0 /)$.

\begin{abstract}
The functioning of various agroecosystems is nowadays shaped by different farming systems, which may impair their functions, as well as being beneficial to them. The benefits include ecosystem services, defined as economic and noneconomic values gained by humans from ecosystems, through supporting soil formation and nutrient circulation, and the impact of agriculture on climate and biodiversity. Their mutual flow and various disturbances depend on the agroecosystem's management method, which is associated with the type of management of agricultural land (AL) in individual farms. This paper raises a problem of transformation in the structure of three main farming systems in Poland, in 2004-2018, in relation to the implementation of 16 selected ecosystem services and their scale. Special attention was given to organic farming, as the most environmentally friendly and sustainable. The analysis demonstrates the increase in ALs in that type of production during the analyzed period of time. Disparities of transformation associated with the type of agricultural system were noticeable at the regional level, which were presented in 16 Polish voivodeships. The results of the analysis confirm that the organic system, which is an important carrier of various ecosystem services, gained a stable position. Moreover, areas with integrated farming still do not exceed $0.5 \%$ of total agricultural lands in such voivodeships. The analysis of factors influencing the deterioration or disappearance of selected environmental services characterizing agricultural systems indicates the need to depart from an intensive conventional management system.
\end{abstract}

Keywords: ecosystem services; structure of agricultural land; regional differentiation of farming systems

\section{Introduction}

The increasing demand for food associated with human population growth on a global scale has led to a considerable boost in the need for food production, which has been occurring as early as the 19 th century. In 1850, the general expansion of various crops led to conversion into agroecosystems of approximately 6 million $\mathrm{km}^{2}$ of forests, 4.7 million $\mathrm{km}^{2}$ of savannahs, and areas covered by various types of grasslands. In this way, $40 \%$ of land areas have been gradually transformed into arable lands [1,2]. Despite the fact, that land use has generally been considered a local environmental issue, nowadays, it is becoming a force of global importance. Worldwide changes to forests, farmlands, waterways, and air are being driven by the need to provide more food, fiber, water, and shelter to still growing populations of people. Global croplands, pastures, plantations, and urban areas have expanded in recent decades, accompanied by large increases in energy, water, and fertilizer consumption, along with considerable losses of biodiversity [3]. Such changes in land use potentially undermine the capacity of ecosystems to sustain food production, maintain freshwater and forest resources, and regulate climate and air quality. As a result, we face 
the challenge of managing trade-offs between immediate human needs and maintaining the capacity of the biosphere to provide goods and services in the long term.

Current European agriculture consists of three basic farming systems in the agricultural space: plant and animal production and their processing [4-6]. The basis for identifying these systems is the level of dependence of farming on the industrial production measures and environmental impact [7]. Thus, the type of farming system is determined with a view to production inputs, and also environmental and socio-economic sustainability [8]. A farming system that is focused on maximizing profits achieved by a high yield of plant and animal species is called conventional. Production technologies applied in this system are based on considerable consumption of industrial resources, and low labor inputs [9]. Common use of chemicals to maximize yield resulted in considerable production progress. It was additionally boosted by biotechnology development promoting new, more resistant animal breeds and plant varieties. This has been, however, accompanied by a reduced range of plant species cultivated at particular farms. Animal production in this system switches towards farming of large herds, usually of a single species [10].

The negative environmental impact of farming and the increasing problem of adverse effects of intensive agricultural practices contributed to the implementation of the organic farming concept during a scientific conference in Atlanta in 1981. According to that idea, it was considered as promoting the sustainable use of environmental resources. Organic systems activate natural production schemes by applying technologically non-processed resources, which ensures continuous soil fertility and animal health, as well as a high biological quality of agricultural products [11]. Maintaining and enhancing soil fertility by promoting plant and animal species that are resistant to diseases are preferred in this system. As it originates from the holistic approach, organic agriculture is subordinated to the rhythm of natural processes and therefore does not disturb the balance of nature [12,13]. It also promotes animal welfare and the conservation of existing genetic resources [14].

In the first decade of the 21st century, the area of organic farmlands on a global scale has increased from 11 million to 32 million ha. The largest areas of such farms are recorded in Australia, and South America [15]. Their structure is dominated by grasslands, primarily pastures, the share of which accounts for $95 \%$ in Australia. Additionally, in the European Union, organic farming is developing dynamically. Since 2008, there has been an average annual growth rate of $8 \%$, more than 500 thousand ha have been converted into organic cultivation each year for the past decade, and the potential for further growth remains strong. Land converted to farms with organic cultivation in Europe in 2014 represented just $5.4 \%$ of the EU's total utilized agricultural area [16]. In Poland, the concept of organic farming was practically introduced in 2004, thus at the time of the accession to the EU. Development of this system during the last 17 years is strongly related to the implementation of the national agri-environmental programs of the CAP [8].

The concept of integrated farming systems appeared in Western Europe in the 1980s, in order to protect the environment of rural areas and simultaneously maintain the competitive advantage of such farms on the market. This system enables the delivery of economic and environmental objectives by means of aware use of advanced production technologies, regular enhancement of management, and implementation of various forms of biological progress [17]. Similarly, being organic, the integrated system is called holistic, since it combines natural processes with agricultural activity in order to gain a satisfactory income, subject to the lowest possible interference in nature [18].

According to Daily et al. [19], ecosystem services are the conditions and processes through which natural ecosystems, and species that constitute them, sustain and fulfil human life. In addition to the production of some ecosystem goods, such as forage, timber, and biomass fuels, ecosystem services have actual life-supporting functions, such as: cleansing, recycling, and renewal. Services of ecological systems, and the natural capital stocks that produce them, are critical to the functioning of the Earth's life-support system. They contribute to human welfare, both directly and indirectly, and therefore represent 
part of the total economic value of the planet [20]. In global terms, in ecosystem services, the crucial role is played by climate, soils, biodiversity, and pollinators [3,19]. Intensive farming of land contributes to climate change, aggravating erosion, soil degradation, and biodiversity loss [21-24]. Environmental services that will be impaired as a consequence of disturbances to ecosystem functions are as follows: climate regulation, pest control, water retention, and maintenance of soil processes. According to the Report of the Millennium Ecosystem Assessment [25], in 2005, almost 60\% of global ecosystem services, such as drinking water, fisheries, pest control, and water and air purification, were degraded at some point. Factors responsible for that phenomenon were as follows: climate change, habitat degradation, and the accumulation of nutrients. The leading thesis of the study was the existence of a direct relationship, confirmed by the scientific literature, between agricultural production carried out by the farms in different Polish regions, according to the criteria for a specific farming system, and receiving the selected ecosystem services which in fact are provided by these farms.

\section{Materials and Methods}

The term "ecosystem service" was established in the 1980s, in the context of justification for biodiversity conservation [26]. Ecosystem services are generally defined as economic and noneconomic values gained by humans both from natural and agricultural ecosystems [27-29]. They contribute to human welfare, both directly and indirectly, and therefore represent part of the total economic value of the planet [20]. When referring to landscape-related issues, Polish scientific terminology more frequently uses the term "services for ecosystem", which in fact applies to the same phenomenon. According to Wieliczko [30], the importance of agriculture in generating organic services, and the impact of this sector on human well-being, can be both positive and negative.

Particular ecosystem services were assessed and highlighted on the basis of a literature study: $[19,20,25,26,30-36]$. Then, they were assigned to the specific farming systems, by creating and using a scale in order to estimate the degree of implementation of such individual services (from a high level to a lack of the factor). The factors contributing to the deterioration or disappearance of selected ecosystem services in agroecosystems that are managed in 3 different farming systems (with the degree of intensity of a given factor in each system) were also singled out. Actions in the area of agricultural production were also indicated that negatively affect the implementation of ecosystem services.

A farming system, according to Niewiadomski [7], is a way of managing the agricultural space in terms of plant and livestock production, and processing their products. It is valued by using some selected criteria, both economic and ecological. In Polish agriculture, there are three main farming systems that have been distinguished: conventional (intensive, industrialized), organic (biological, bio-organic, etc.), and integrated (harmonious, balanced) $[10,12]$.

In Poland, since 1999, a new territorial division has been functioning, consisting of 3 levels, according to which the territory of the country has been divided into 16 voivodeships (Figure 1). They form smaller administrative units, such as counties and communes [37]. Those voivodeships are often, at the same time, the separate regions, meaning they can be fields for analyses of various types. The analysis of different farming systems regarding the differentiation of the agricultural land structure covered the period of 2004-2018 and was carried out on the basis of data available in the Statistical Yearbooks of Agriculture [37]. The examined data describe the area of agricultural lands (ALs) (ha), in all voivodeships of Poland, which correspond to such individual regions of the country. These data were presented for the three farming systems: integrated, organic, and conventional. 


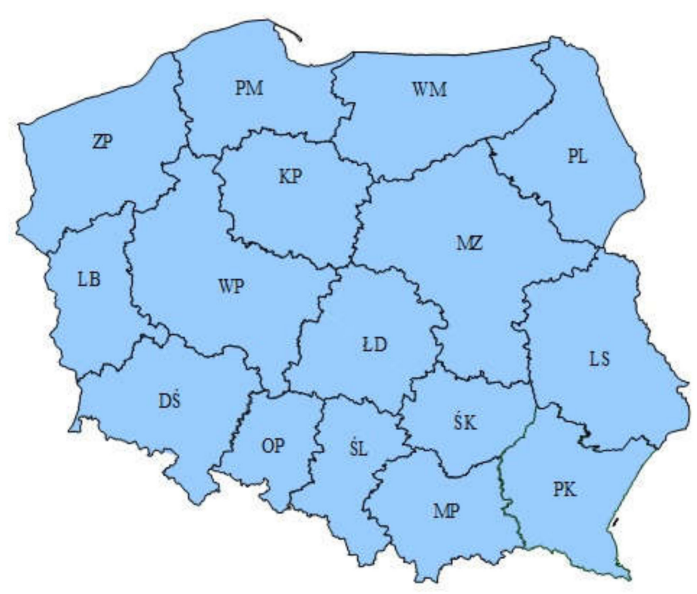

\section{Names and abbreviations (from the Polish abbrevia- tion) of the voivodships}

West Pomerania (ZP), Pomerania (PM),

Warmia-Masuria (WM), Lubusz (LB),

Greater Poland (WP), Kuyavia-Pomerania (KP),

Masovia (MZ), Podlasie (PL), Lublin (LS),

Subcarpathia (PK), Lesser Poland (MP), Holy Cross

(SK), Silesia (SL), Lodz (LD), Opole (OP),

Lower Silesia (DS)

Figure 1. The administrative division of Poland into 16 voivodeships. Source: own study based on [37].

In order to determine the pace of changes to the structure consisting of $m$ components, described in time $t$ and $t+1$, we used the following vectors:

$$
\begin{aligned}
& S_{t}=\left[\begin{array}{llll}
\alpha_{1 t} & \alpha_{2 t} & \ldots \ldots & \alpha_{m t}
\end{array}\right], \\
& S_{(t+1)}=\left[\begin{array}{llll}
\alpha_{1(t+1)} & \alpha_{2(t+1)} & \ldots \ldots & \alpha_{m(t+1)}
\end{array}\right],
\end{aligned}
$$

where $\alpha_{j t}, \quad \alpha_{j(t+1)}$ mean a share $j$ of a structure component in the period of $t$ and $t+1$, and $t=0,1,2, \ldots, k$, respectively, and the following measure was applied [38]:

$$
v_{t, t+1}=\frac{1}{2} \sum_{j=1}^{m}\left|\alpha_{j(t+1)}-\alpha_{j t}\right|
$$

Value $v_{t, t+1}$ determines the level of changes to the structure in the period from $t+1$ to $t$. This measure takes the values from the $[0,1]$ range, provided that its higher value translates into greater changes to the structure.

Average measure values $v_{t, t+1}$ were calculated from the formula:

$$
\bar{v}=\frac{1}{n} \sum_{t=0}^{n-1} v_{t, t+1}
$$

The structure of agricultural land areas according to the adopted farming systems in a single study year in the voivodeships of Poland may be presented in the form of matrix $\left[a_{i j}\right]$ :

$$
\left[a_{i j}\right]_{i=1,2, \ldots, n}=\left[\begin{array}{cccc}
a_{11} & a_{12} & \ldots \ldots \ldots & a_{1 m} \\
a_{21} & a_{22} & \ldots \ldots \ldots & a_{2 m} \\
\ldots & \ldots & \ldots \ldots \ldots & \ldots \\
\ldots & \ldots & \ldots \ldots \ldots & \ldots \\
a_{n 1} & a_{n 2} & \ldots \ldots \ldots & a_{n m}
\end{array}\right]
$$

where $a_{i j}$ describes the share of the number of farms from $j$ area group in the number of all farms in $i$ voivodeship, provided that the following conditions are met: $0 \leq a_{i j} \leq 1$ and $\sum_{j=1}^{m} a_{i j}=1, i=1,2, \ldots, \quad n$.

For each pair of voivodeships in a given year, the differentiation measure was assigned according to the formula

$$
d_{i k}=\frac{1}{2} \sum_{j=1}^{m}\left|\alpha_{i j}-\alpha_{k j}\right|
$$


Element $d_{i k}$ in one year forms a symmetric matrix $\left[d_{i k}\right]_{i, k=1, \ldots, n}$.

The basis for the division of voivodeships into groups similar in terms of the analyzed structure was the transformation of matrix $\left[d_{i k}\right]_{(i, k=1, \ldots, n)}$ in a binary similarity matrix $\left[p_{i k}\right]_{(i, k=1, \ldots, n)}$, element $p_{i k}$ of which is defined as follows:

$$
p_{i k}= \begin{cases}0, & d_{i k}<d^{*} \\ 1, & d_{i k} \geq d^{*}\end{cases}
$$

where threshold value $d^{*}$ in a given year is at the level of

$$
d^{*}=\frac{2 \sum_{i=1}^{n} \sum_{k>i} d_{i k}}{n(n-1)}
$$

Matrix $\left[p_{i k}\right]_{(i, k=1, \ldots, n)}$ constitutes the baseline for grouping the voivodeships in accordance with the vector elimination procedure [39].

\section{Results}

3.1. Implementation of Ecosystem Services and Evaluation of Environmental Threats in Different Farming Systems

It is commonly believed that at the initial stages of agricultural development, extensive farming enhanced the spread of certain species other than arable crops. That refers primarily to species of weeds that are currently rare in Poland, accompanied by cereals and root crops, which are called archeophytes. Various economic activities of humans allowed them to increase their ranges of occurrence. This is why, in low-invasive phases of the human impact on nature, we may speak about its positive effect on the increase in local biodiversity. Currently, however, the farming specific to the European systems frequently demonstrates a negative impact on both the environment and biodiversity [40]. This refers primarily to strengthening of the industrial farming negative effects on local ecosystems (Tables 1 and 2). The above is also promoted by land consolidation, i.e., the procedure valued for technological purposes and aiming at promoting large and straightly delimited arable fields. Such fields are also characterized by simplified crop rotations, high fertilization rates, and the use of chemicals which guarantee a high yield and are decisive for production profitability. Land consolidation also contributes to elimination of traditional balks and midfield paths, and the disappearance of xerothermic plants from the Festuco-Brometea class, accompanied by field weeds [41]. Thus, mosaic communities supporting the maintenance of the biodiversity of species coexisting with farming and contributing to environmentally attractive and tourist-attractive cultural landscapes stand in strong opposition to economic purposes.

\begin{tabular}{|c|c|c|c|c|}
\hline \multicolumn{5}{|c|}{ Selected Ecosystem Services That Are Implemented by Farms in Different Farming Systems and Their Scale } \\
\hline \multirow{2}{*}{ No. } & \multirow{2}{*}{ Maintaining/Supplying } & \multicolumn{3}{|c|}{ Farming System } \\
\hline & & Integrated & Organic & Conventional \\
\hline 1. & Proper water management & + & ++ & - \\
\hline 2. & Climate protection & ++ & ++ & - \\
\hline 3. & Limited soil erosion & + & ++ & - \\
\hline 4. & Nutrients in the soil & ++ & +++ & + \\
\hline 5. & Environmental pollination of plants & ++ & +++ & + \\
\hline 6. & Biological protection against pests & + & +++ & - \\
\hline 7. & Diversified crops & ++ & +++ & + \\
\hline 8. & Crop rotation & ++ & +++ & + \\
\hline
\end{tabular}

Table 1. Evaluation of ecosystem services in different farming systems. 
Table 1. Cont.

\begin{tabular}{|c|c|c|c|c|}
\hline \multicolumn{5}{|c|}{ Selected Ecosystem Services That Are Implemented by Farms in Different Farming Systems and Their Scale } \\
\hline \multirow{2}{*}{ No. } & \multirow{2}{*}{ Maintaining/Supplying } & \multicolumn{3}{|c|}{ Farming System } \\
\hline & & Integrated & Organic & Conventional \\
\hline 9. & Intercropping & ++ & +++ & + \\
\hline 10. & Limited size of farmlands & ++ & +++ & - \\
\hline 11. & Mosaic-like cultural landscape & +++ & +++ & ++ \\
\hline 12. & Maintaining seminatural grasslands & ++ & +++ & + \\
\hline 13. & Maintaining balks, field paths, and shrubbery & +++ & +++ & + \\
\hline 14. & $\begin{array}{l}\text { Maintaining biodiversity of species coexisting } \\
\text { with agriculture }\end{array}$ & ++ & +++ & + \\
\hline 15. & Maintaining native breeds of livestock & ++ & +++ & - \\
\hline 16. & Animal welfare & ++ & +++ & - \\
\hline
\end{tabular}

Scale of implementation of the ecosystem service: +++: high level; ++: average level; +: low level; -: lack of the factor. Source: own study based on: $[30,31,35,36,42-44]$.

Conventional farming is focused on a rapid economic effect with no consideration of the negative impact on nature, which results in numerous environmental disturbances. This includes, among others, the introduction of massive use of artificial fertilizers and plant protection products. Despite the fact that the latter have significantly changed over time, in terms of application, selectivity, and the level of threat to the environment, it seems that they have reduced biodiversity in an irrevocable manner. That refers, in particular, to field weed communities of the Stellarietea mediae class of plants [41,42,45]. The factor disturbing such balance in the agroecosystems is also focusing on the cultivation of one-two plant species or farming of one species of livestock of highly intensive breeds, which is usually a nonindigenous species for the territory of Poland; however, it features very good production parameters. Intensive cultivation of one plant species, especially on a large scale, disturbs environmental pollination of plants and biological protection against pests. Moreover, due to the lack of a proper crop rotation and diversified crops including intercropping, such intensive production contributes to accelerating soil erosion. Abandonment of typical cultivation procedures, such as crop rotation, whilst maintaining diversified crops and intercrops results in the gradual appearance of plant species that are natural for the specific climate zone, which for Poland is a deciduous forest. That is also reflected by the disappearance of a mosaic-like cultural landscape, with various different habitats that are both of natural and seminatural characters, especially those that prefer moderate and full light [46,47].

Table 2. Factors contributing to deterioration or disappearance of selected environmental services in different farming systems.

\begin{tabular}{|c|c|c|c|c|}
\hline \multirow{2}{*}{$\begin{array}{c}\text { Factors Impairing Ecosystem } \\
\text { Services }\end{array}$} & \multirow{2}{*}{ No. of Ecosystem Services } & \multicolumn{3}{|c|}{$\begin{array}{l}\text { Intensity of the Factor in } \\
\text { a Farming System }\end{array}$} \\
\hline & & Integrated & Organic & Conventional \\
\hline Consolidation of farmlands & $10,11,13,14$ & ++ & + & +++ \\
\hline Greenhouse gases emissions & 2 & ++ & + & +++ \\
\hline Use of pesticides & $1,3,4,5$ & + & - & +++ \\
\hline Intensive fertilization (NPK) & $1,3,4,5$ & ++ & - & +++ \\
\hline Deterioration of water quality & 1 & ++ & + & +++ \\
\hline Progressive water eutrophication & 1 & ++ & - & +++ \\
\hline
\end{tabular}


Table 2. Cont.

\begin{tabular}{ccccc}
\hline Factors Impairing Ecosystem & No. of Ecosystem Services & \multicolumn{3}{c}{$\begin{array}{c}\text { Intensity of the Factor in } \\
\text { a Farming System }\end{array}$} \\
\cline { 3 - 5 } Services & & Integrated & Organic & Conventional \\
\hline $\begin{array}{c}\text { Long-term consequences of soil } \\
\text { fertility decline }\end{array}$ & 3,4 & + & + & ++ \\
$\begin{array}{c}\text { Intensive cultivation of } 1-2 \text { plant } \\
\text { species }\end{array}$ & $1,2,3,4,5,6,7,8,9,10,11,12,13$, & ++ & + & ++ \\
Intensive breeding of 1-2 species & 14 & + & + & ++ \\
of animals & $1,2,3,4,10,11,12,14,15,16$ & ++ & ++ \\
Abandoning agricultural land use & $10,11,12,13,14$ & +++ & +++ & ++ \\
Lack of ruminant grazing & $11,12,13,14,15,16$ & ++ & + & ++ \\
Application of genetic engineering & $14,15,16$ & + & - & ++ \\
\hline
\end{tabular}

The specific ecosystem services (from Table 1 ) that are impaired by the selected factors. The degrees of intensity of a given factor impairing environmental services are as follows: +++ : at the high level; ++: at the average level; +: at the lower level; -: lack of occurrence of the factor. Source: own study based on: [25,31,42,48,49].

Intensive production of livestock, which in Polish conditions especially concerns cattle and pigs, favors the increase in $\mathrm{CO}_{2}, \mathrm{CH}_{4}, \mathrm{~N}_{2} \mathrm{O}$, and $\mathrm{NH}_{3}$ emissions that are the greenhouse gasses contributing to climate change [50,51]. Such type of production also results in the further deterioration of the water quality and progressive water eutrophication. The lack of ruminant grazing, which is most common on a large scale, and intensive animal production are other factors impairing ecosystem services, such as: maintaining the seminatural grasslands and biodiversity of such habitats, as well as impoverishing the mosaic cultural landscape. They are also unfavorable in terms of sustenance of animal welfare. Application of genetic engineering is also a factor deteriorating the quality of some of the ecosystem services. It favors highly productive breeds of livestock, at the same time displacing the native breeds that are elements of the local biodiversity. Ruminants, such as cattle and sheep, kept in such farming systems in agricultural lands contribute to the maintenance of grasslands, which in Polish environmental conditions are mostly meadows and pastures, but, on a smaller scale, also dry and poorer grasslands represented by xerothermic vegetation $[30,32]$.

Integrated farming uses plant protection products, fertilizers, and liquid manure, and these resources are applied at strict, minimum levels to prevent the spread of bioelements outside the agroecosystems. Plant production compliant with the site condition and crop rotation recommendations are promoted with the focus on cultivation of leguminous plants and intercrops, which addresses the concept of ecosystem services. The following issues are also of high importance: reducing the size of farms to a maximum of 75-100 ha, in order to prevent the use of chemicals, and intensification of production, in order to comply with environmental protection requirements.

Organic farming is the carrier of various ecosystem services and has many opportunities for their practical use. It contributes to the maintenance of the cultural landscape and preservation of biodiversity. Moreover, it mitigates the process of water and soil contamination and even contributes to improving their quality [42]. The activities applied by organic farmers, being the agroecosystem services, cover, among others: the introduction of long-term, diversified crop rotations, maintenance of soil fertility, and supplying nutrients. In the scope of plant production organization in organic farming, a noticeably lower share of cereals in the agricultural land structure has been recorded (by approximately $25 \%$ ) [35,43]. This is associated with the production of plants from the Fabaceae family capable of binding the atmospheric nitrogen and enriching soil in this element. Organic fertilizers promote biodiversity of soil microorganisms, constitute the source of nutrients for plants, improve the soil structure, and prevent erosion [52]. Prohibition on using synthetic mineral fertilizers and chemical plant protection products allows some long-term changes in the chemical composition of soil to be avoided. In addition, ruminant grazing on various pastures enables the maintenance of seminatural meadow and pasture 
ecosystems, requiring human impact in the form of mowing or grazing [46]. Ecosystem services in organic farms also include intercropping, which protects the soil by preventing erosion and nutrient leaching. Maintenance of balks, field paths, and shrubbery is also of importance for biodiversity preservation, counteracting erosion and the retention of rainwater. In addition, organic farming allows the maintenance, and even improvement, of the water quality by reducing the volume of the applied agricultural chemicals which penetrate into water reservoirs and lead to water contamination.

\subsection{Differentiation of Agricultural Land Structure in Good Agricultural Practice}

In Poland, the conventional farming system still remains the dominating one throughout the country (Table 3). However, the share of agricultural lands (ALs) in good agricultural practice in the conventional system demonstrates a certain downward trend, but these changes are rather slow.

Table 3. Share of agricultural lands in good agricultural practice in Poland by farming system in: 2004, 2010, and 2018.

\begin{tabular}{cccc}
\hline \multirow{2}{*}{ Year } & \multicolumn{3}{c}{ AL Share by Farming System (\%) } \\
\cline { 2 - 4 } & Integrated & Organic & Conventional \\
\hline 2004 & 0.04 & 0.51 & 99.45 \\
2010 & 0.05 & 3.59 & 96.35 \\
2018 & 0.15 & 3.33 & 96.51 \\
\hline
\end{tabular}

Source: own study based on GUS [37].

Average changes to the area structure of agricultural lands in Poland as a whole in 2004-2018 are specified by the value $\bar{v}=0.004 \bar{v}=0.004$. Larger than average changes to the discussed structure were recorded in 2010 comparing to 2009 (Figure 2). Throughout the years, no stable direction of changes was determined.

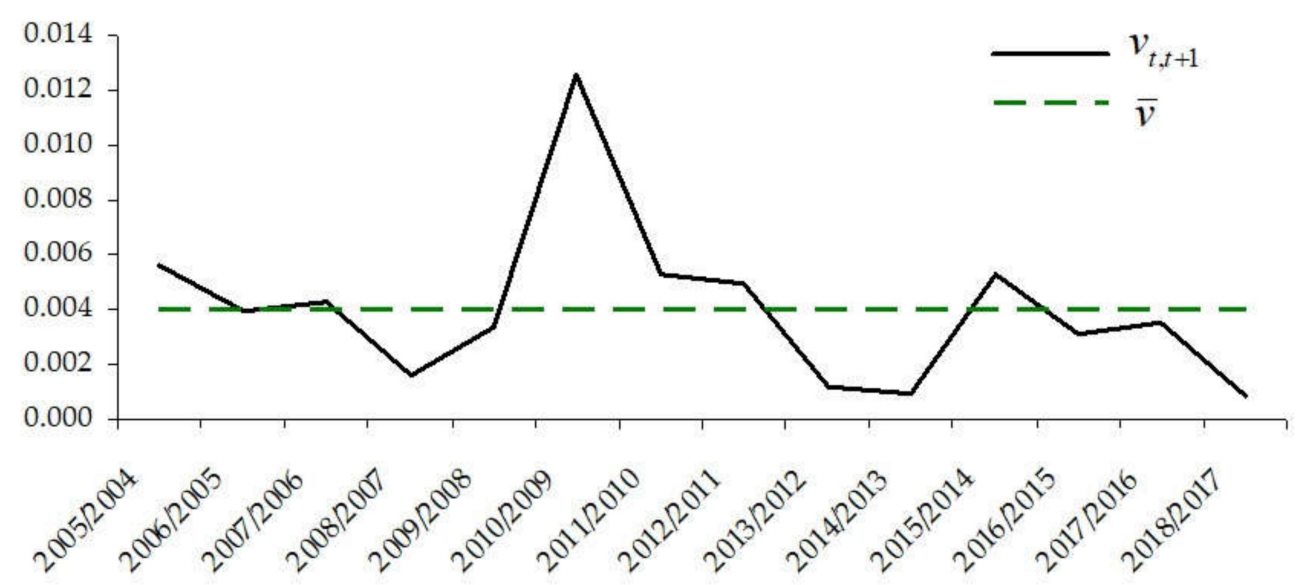

Figure 2. Course of changes of measure of dynamics $\left(v_{t, t+1}\right)$ for the area structure of agricultural lands in good agricultural practice by the system in Poland in (2004-2018). Source: own study based on GUS [37].

Throughout the analyzed years, the changes in the structure of agricultural lands (ALs) by farming systems were regionally differentiated. In 2010 and 2018, the average differentiated estimation, according to Formula (8), of the AL area structure by farming systems in Polish voivodeships amounted to 0.034 and 0.038 , respectively. Some increase in these values demonstrates that the differences between the voivodeships increased, yet slightly. Adopting these values as threshold values, the groups of similar voivodeships were identified each year (Table 4, Figure 3). 
Table 4. Average shares of AL area of the farms in Poland by farming system in 2010 and 2018.

\begin{tabular}{ccccc}
\hline \multirow{2}{*}{ Specification } & \multicolumn{2}{c}{ AL Share by Farming System (\%) } \\
\cline { 2 - 5 } & & Integrated & Organic & Conventional \\
\cline { 2 - 5 } 2010 & group I & 0.058 & 3.04 & 96.9 \\
& group II & 0.001 & 4.14 & 95.9 \\
& group III & 0.018 & 5.19 & 94.8 \\
& group IV & 0.018 & 5.93 & 94.1 \\
& group I & 0.155 & 1.72 & 98.1 \\
& group II & 0.004 & 4.82 & 95.2 \\
& group III & 0.010 & 10.78 & 89.2 \\
\hline
\end{tabular}

Source: own study based on GUS [37].

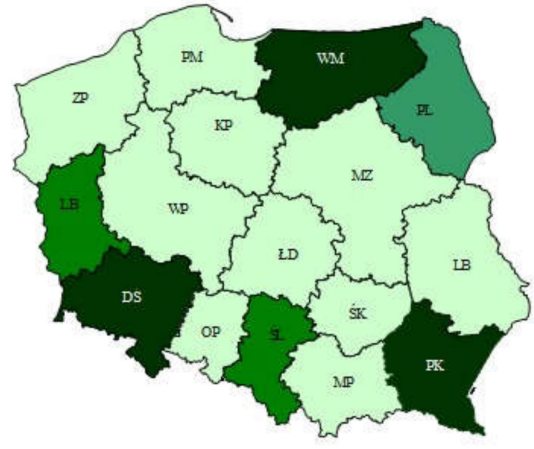

2010

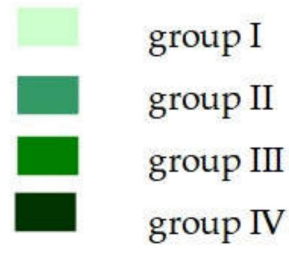

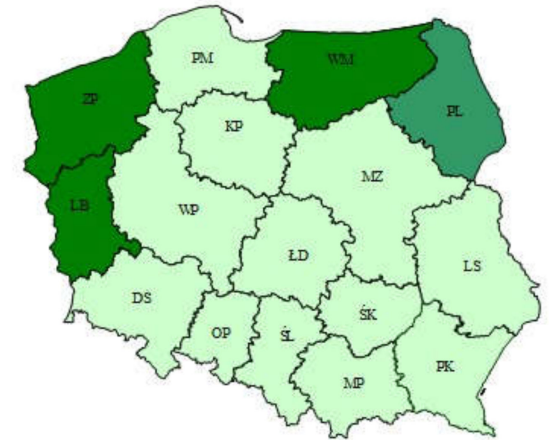

2018

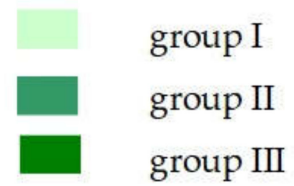

Figure 3. Groups of voivodeships similar in terms of AL structure in Poland in 2010 and 2018 (abbreviations are the same as in Figure 1). Source: own study based on GUS [37].

In 2010, there were four groups of voivodeships (regions) of a similar AL area by farming systems in Poland. Group I consisted of 10 voivodeships, in which the share of the area of ALs using conventional methods was the highest and, on average, accounted for $96.9 \%$ (Table 4). Thus, the average share of the area of agricultural lands in organic farms or farms with integrated production methods was the lowest. In group II, consisting only of the Podlasie Voivodeship (PL), situated in the north-eastern part of Poland, 95.9\% of agricultural lands were covered with the conventional system, while the remaining ALs were used primarily as organic farms. In the next two groups (III and IV), on average, 5.19\% and $5.93 \%$ of agricultural lands, respectively, were cultivated outside the conventional system.

Basing on the data from 2018, three groups of similar voivodeships were identified. Group I was represented by the regions in which, in the research year, the share of ALs used within the conventional system was the highest. On average, it accounted for $98.1 \%$. Similar to 2010, Podlasie (PL) was classified into a single-item group; however, the share of agricultural lands in organic farms increased slightly, while the share of lands covered by integrated production decreased comparing to 2010. Group III consisted of three voivodeships: West Pomerania (ZP) and Lubusz (LB), located in the north-western part of Poland, and Warmia-Masuria (WM), situated in the northern part of the country. Their common feature was the highest average share of agricultural lands cultivated in systems other than the conventional system. 


\subsection{Development of Organic Farming and Farming Applying Integrated Production Methods}

In 2004, there were 3760 organic farms in Poland, while in 2018, their number increased to 19,207 (Figure 4). This resulted in an increase in the average area of organic farms, estimated at 25.2 ha in 2018 . The total area occupied by integrated farms increased from 6452 to 22,119 ha. The share of agricultural lands in Poland in organic farms, in the total area of agricultural farms (AL), in 2004 accounted for only $0.51 \%$. Within 15 years, this indicator increased more than six times.

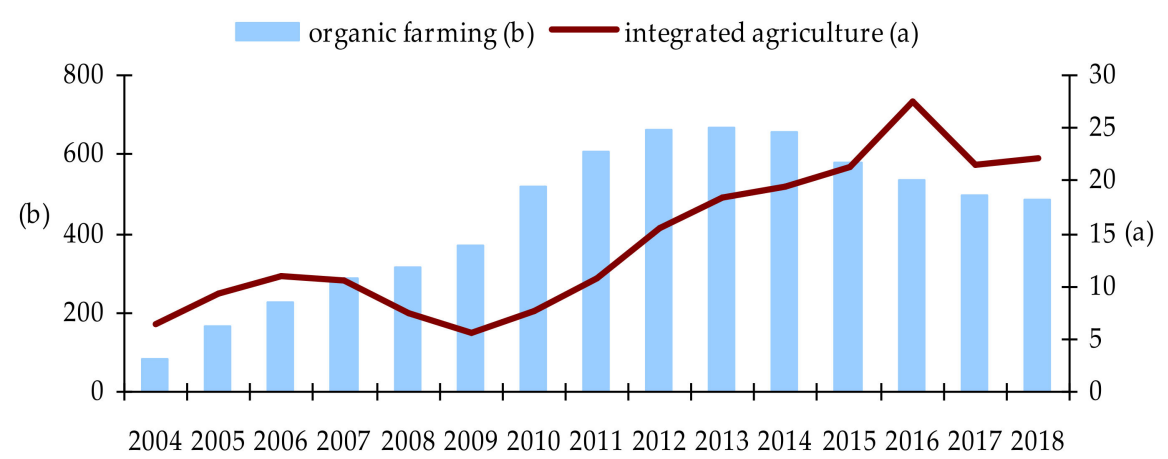

Figure 4. Area of organic farms and farms using integrated production methods in Poland in 2004-2018 (thousand ha). Source: own study based on GUS [37].

Similar favorable changes took place in the farms applying integrated production methods. Despite the fact that the share of such farms in the total number of agricultural farms is minor and accounted for only $0.15 \%$ in 2018 , there has been an increasing number of farmers contributing to biological and technical progress in cultivation, fertilization, plant protection, and animal breeding in a sustainable manner. Owners applying integrated production methods use industrial production measures (mineral fertilizers, pesticides, synthetic additives to fodder) in moderate quantities, which are safe for the environment, as well as for human and livestock health. In 2004-2018, the area of farms applying integrated production methods grew by $243 \%$. The number of such farms increased more than three times.

The development of organic farming and farms applying integrated production methods is still regionally differentiated (Table 5). The coefficients of variation of the vast majority of specifications were high both in 2010 and in 2018 and demonstrated an upward trend. Only the average area of organic farms demonstrated average differentiation, although differentiation between the voivodeships increased. In 2018, the area of farms applying integrated methods grew significantly, comparing to 2010. The maximum area of these farms in a voivodeship amounted to 3029 ha in 2010, while in 2018, it reached 11,727 ha. The average share of farms applying integrated production methods in the voivodeships enlarged from $0.042 \%$ to $0.119 \%$ within eight years, i.e., nearly two times.

In 2010, and only in West Pomerania (ZP), the share of organic farms in the total area of agricultural lands in good agricultural practice exceeded 10\% and amounted to $11.25 \%$ (Figure 5). After eight years, only that voivodeship, together with Warmia-Masuria (WM), reached the threshold of $10 \%$. It should be noted that positive changes took place also in the Lubusz (LB), Podlasie (PL), Lodz ( $\mathrm{ED}$ ), and Opole (OP) Voivodeships, where comparing to 2010, the share of areas covered by organic farms increased. In the remaining voivodeships, the value of this indicator declined. The area of agricultural lands with organic farming recorded the most considerable decrease in Subcarpathia (PK), Lesser Poland (MP), and Lower Silesia (DŚ), by 3.11 pp, 2.24 pp, and 1.21 pp, respectively. The share of ALs covered by integrated production in 2010 exceeded 0.5\% only in Masovia (MZ). In 2010-2018, this indicator increased in the vast majority of the voivodeships. Decreases were recorded only in the Lower Silesia (DŚ), Kuyavia-Pomerania (KP), Opole (OP), Greater Poland (WP), and West Pomerania (ZP) Voivodeships. 
Table 5. Selected characteristics of organic farms and farms applying integrated production methods in the voivodeships in Poland, in 2010 and 2018.

\begin{tabular}{cccccc}
\hline \multirow{2}{*}{ Specification } & \multicolumn{2}{c}{ Integrated System } & \multicolumn{2}{c}{ Organic System } \\
\cline { 3 - 6 } & & Area (ha) & \% of Total AL & Area (ha) & \% of Total AL \\
\hline \multirow{2}{*}{2010} & min & 1 & 0.000 & 3180 & 0.6 \\
& max & 3029 & 0.159 & 98023 & 11.2 \\
& median & 155 & 0.027 & 32190 & 2.9 \\
& mean & 474 & 0.042 & 32442 & 3.9 \\
& CV * & 157.5 & 110.2 & 76.6 & 76.8 \\
\hline \multirow{2}{*}{2018} & min & 3 & 0.001 & 2951 & 0.7 \\
& max & 11,727 & 0.550 & 104574 & 11.4 \\
& median & 298 & 0.044 & 22984 & 3.0 \\
& mean & 1382 & 0.119 & 30292 & 99.8 \\
\hline
\end{tabular}

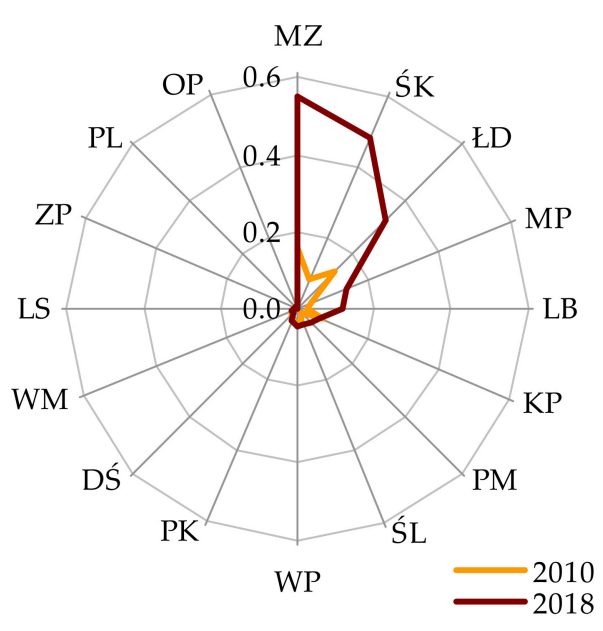

(a)

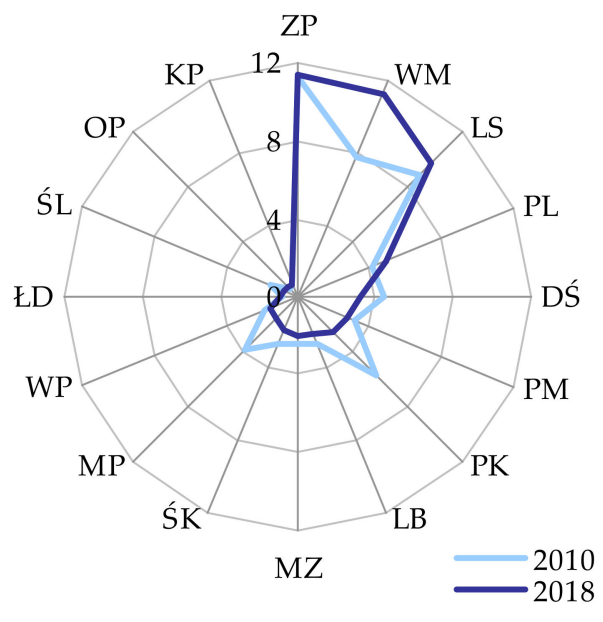

(b)

Figure 5. Share of the area under integrated production methods (a) and the area of organic farms (b) in the Polish voivodeships in 2010 and 2018 (\%) (abbreviations are the same as in Figure 1). Source: own study based on GUS [37].

\section{Discussion}

Despite the significant range of intensive farming in Poland, still many protected species inhabit the arable lands. These are usually associated with various seminatural ecosystems, from wetlands and peat bog sites located in the river valleys, to the communities from the other end of the ecological scale, covering xerothermic grasslands. Their maintenance and, in effect, preservation of biodiversity of such habitats, part of which includes agroecosystems, depend on appropriate use $[48,50,53,54]$. Environmental services are weakened if ecosystem services are disturbed, and this problem is nowadays well known from the experiences of many well-developed countries. As a result, we can observe impaired climate regulation, pest control, and water retention, an increase in habitat and soil degradation, and accumulation of nutrients. Therefore, in global terms, in ecosystem services, the crucial role is played by climate, soils, biodiversity, and pollinators [19]. Intensive farming of land contributes to climate change, aggravating erosion, soil degradation, and biodiversity loss [21-24]. Thus, it seems that supporting ecosystem services, i.e., enhancing soil formation and nutrient circulation, is of high importance [33,34]. Their mutual flow, as well as various disturbances, depends on the agroecosystem management method, which is associated with farming systems. In recent years, the awareness and understanding of this process have been increasing due to translating these services into economic value [45]. 
Supporting and achieving ecosystem services may be realized by the implementation of various agri-environmental programs. This applies well to the specific feature of Polish agriculture, which is a considerable diversification, both naturally and structurally, in different voivodeships (regions) of the country. This differentiation may be enhanced by new proposals for ecologization of agriculture presented in the new Common Agricultural Policy (CAP) 2021-2027. A novelty in the approach to challenges related to environmental protection are eco-schemes, within Pillar I of the CAP 2021-2027 [55]. They are agricultural practices designed to impact both the environment and climate, involving various beneficial operations. Their potential role in improving biodiversity on farmlands has been seen within the scientific literature in almost the last two decades [56-58]. Eco-schemes or agri-environment schemes (AES) [55], implemented in organic farming, may provide some ecosystem services in response to seminatural habitat change, by helping to sustain and encourage the idea of ruminant grazing in different types of grasslands, as well as diversifying a range of crops, and expanding crop rotation. Furthermore, support is planned for such agricultural practices that will contribute to the reduction in ammonia emissions, help eliminate fertilizers, and prevent soil erosion. This type of support is designed for processes that set out to improve water retention in arable land by managing crop residues, and for those that involve a change in the use of permanent pastures. Such assistance is connected with the regulatory system that will have an impact on the development of that farming system, which is created at both the EU level and the national level. The latter refers especially to the amounts of payments [55]. This should involve increasing the funds, but also supporting the development of organic production and strengthening ecosystem services through new regional funds at the voivodeship level. This does not have to concern agriculture itself and be limited only to organic farms but can also cover the sphere of educating farmers and local entrepreneurs, and also building and supporting the local markets.

The implementation of various agri-environmental programs seems especially crucial, as the main user of the geographical and production area in Poland is still agriculture, which continues to maintain the seminatural ecosystems formed hundreds of years ago. Traditionally, mosaic systems sustained the habitats of many wild vascular plant species, invertebrates, and vertebrates associated with agroecosystems. Further development of conventional farming poses a threat to such habitats. The most severe environmental effects include contamination, and uncontrolled use of genetic engineering [43,54]. Large-scale farms with intensive animal production and increased concentrations of animal fodder and feces contribute to the higher emission of chemical compounds to the air. These include mainly greenhouse gases, as well as reduced sulfur compounds $[50,51,59,60]$. Farms that are run in the conventional system, especially with sole plant production, which includes cultivation of one-two plant species, provide a limited number of ecosystem services. In that system, there is a lack of: diversified crops, crop rotation, biological protection against pests, ruminant grazing (which means abandoning the seminatural grasslands), and maintenance of the biodiversity of species coexisting with agriculture. All those factors are crucial ecosystem services. Such picture becomes, however, more complicated when agricultural production is of a low-input character and is multidirectional. Therefore, the scope of ecosystem services should be considered larger, or even significant, because fertilizers and pesticides are not used on a large scale, and crop rotation and intercropping are maintained $[29,42,51,57,58]$. Furthermore, another negative factor in the progress of conventional or intensive farming results in the largest food production in the history of Homo sapiens, and this also leads to overproduction of food and decreasing prices, and therefore the profitability of agricultural production [61]. Thus, such farming intensification is the source of many negative phenomena, both in environmental and economic terms.

The type of farming system dominating in a given area or region seems to be important, since organic and conventional farming feature definitely distinct approaches to the environment and the use of its resources. Negative environmental impact includes biodiversity loss, groundwater contamination, and greenhouse gas emissions. Such services 
demonstrate high spatial diversification, while their scale and type will be determined both by the farming system and the location of a given farm in specific physiographical conditions. This refers, among others, to: the type of climate, altitude above sea level, soil conditions, and topography. Such differentiation requires determination for the agricultural policy objectives for ecosystem services at the regional level. At present, despite the continuous domination of conventional farming, raising social awareness concerning its harmfulness resulted in the increased interest of environmentally friendly and safe for human and animal health production technologies, which are used in organic and integrated farming [42].

Baum and Majchrzycki [62], considering the environmental conditions of Poland, recommended implementation of the integrated farming model that produces food of a competitive quality and price. This system is a compromise solution with reference to the concept of sustainable development and seems to be optimal in the existing socio-economic conditions. It primarily addresses the reality of family farms in the southern part of Poland. Various studies confirm that changes in the existing farming systems will slowly head towards integrated farming as the sustainable one. This is supposed to favor the viability of rural areas, creating the conditions for its multifunctional development [63]. In organic farms with extensive crop rotation and multidirectional production organized without the use of intensive fertilization, ecosystem services are being realized. The high ecological awareness of farmers and a holistic approach to management are also important here, and hence the contribution to the provision of ecosystem services is considerable. It is important even when the share of these farms in the structure of land use is small or even marginal. Farms which are run in the integrated system are also valuable, though less than organic in terms of providing ecosystem services, because they show an environmentally friendly approach to production, and despite the use of fertilizers and some plant protection products, such impact is lower than in intensive farming [17].

The unused capacity to develop organic production continues to be noticeable. Krasowicz [64] listed the advantages of Poland as a potential exporter of organic food, emphasizing the clean environment in the prevailing part of the country, the low level of chemical use in farming, and the vast labor resources. There are, however, certain limitations, such as farm scattering, that impede the preparation of appropriate batches of raw material, a need to comply with the attestation requirements, and, most of all, the competition from organic farms in Western Europe. According to Nachtman [63], development of such production in Poland may be fostered by growing demand - since the first decade of the 21st century-for organic products, increasing environmental awareness as well as growing wealth and agricultural policy focused on the care of the natural environment. Organic farming tends to withdraw from intensive breeding of livestock, being a main source of gas emissions. It covers the practices enabling maintenance of the cultural landscape on rural areas by preserving the mosaic of fields and accompanying mid-field tree stands, balks, or natural watercourses. Absence of chemicals promotes maintenance of or even an increase in the local biodiversity, by promoting native, often old breeds of livestock and plant varieties [64].

According to statistical analyses, throughout the 15 years covered by this study (20042018), more than a six-fold increase in the share of areas with agricultural lands in the organic system was recorded, which, however, has not yet achieved the optimistic level exceeding 5\% postulated by Krasowicz in 2009 [64]. Moreover, according to Podawca and Dabkowski [65], the greatest recession in establishing organic farms occurred in the Lesser Poland and Silesia Voivodeships. This is certainly connected to the disadvantageous conditions for organic production in these regions. In this period, the area of farms with integrated production methods increased by $243 \%$, while their number grew more than three times. Moreover, a relatively clear regional division by the average area of organic farms is observed throughout the country. The largest farms using this production system are situated in the regions of western Poland. The smallest farms operate in southern Poland, especially in the Lesser Poland Voivodeship, where their average size amounts 
to 11.5 ha. Development of organic farming in Poland from the perspective of production technologies is also promoted by the scattered agricultural structure and the vast labor resources in the agricultural sector, followed by the high share of conventional production technologies fostering switching such farms into organic production methods, while from the perspective of the food market, this is promoted by the increased demand for organic products $[42,66]$.

A simple continuation of this way of thinking is the indication of logical relationships between the share of agricultural land within the organic agriculture and the possibilities of improving the provision of ecosystem services. Hence, in the voivodeships or regions where this share is significant or large, it can be considered that ecosystem services are implemented to a higher degree. The lack or the very small share of the area covered by the organic farming system proves the threats to the environment, which is intensified when the share of conventional and integrated agriculture is significant.

Organic farming is currently one of the fastest growing agricultural sectors in the European Union. Yet, in Poland, the market for organic products is at an early stage of development. Barriers to development are associated with both the area of supply and the demand for organic products, which is increasing but still limited [67]. According to Gołaś [68], since the Polish accession to the EU structures, the domestic organic farming sector has developed dynamically. The number of organic producers increased seven-fold in 2004-2014, and the observed changes were caused by an increase in both the number of ecological farms and organic food processing enterprises. Organic and conventional farms clearly differ in terms of organization, productivity, and profitability. Conventional farms experienced higher rates of productivity, land profitability, and work profitability. Furthermore, the financial situation of organic farms was vastly determined by state subsidies, which constituted almost $80 \%$ of the income accrued from agricultural production [66].

\section{Conclusions}

Due to the significant differentiation of natural, organizational, and economic conditions of different regions of Poland, there are three main farming systems that coexist in the agricultural sector. Over the last decade, organic farming has gained an importance. With reference to the integrated system, an analogical upward trend can be observed only in the last few years. This tendency should be assessed positively, taking into account the fact that the consolidation of land, typical of conventional agriculture, is a point that impairs selected ecosystem services, such as the mosaic cultural landscape. It also negatively affects another ecosystem service, which is the maintenance of biodiversity coexisting with agriculture. Intensive production of livestock, which in Polish conditions especially concerns cattle and pigs, favors the increase in greenhouse gas emissions, contributing to climate change. Such type of production also results in the further deterioration of the water quality and progressive water eutrophication. The assessment of ecosystem services in various agricultural systems indicates the need to move away from an intensive conventional farming system.

The performed analyses demonstrate regional differentiation in the area of ALs using different farming systems. Changes in the AL structure by these systems were observed in the individual Polish voivodeships in 2010-2018. Development of the organic system in 2010 was more intensive in the voivodeships located in the western and south-western parts of Poland (Lubusz, Lower Silesia, and Silesia). These values were also high in Subcarpatia (south-east) and Warmia-Masuria, situated in the northern part of the country. The number of certified and integrated AL areas increased in central Poland. From the perspective of nature conservation and environmental protection, the development of organic farming, which withdraws from the massive use of agricultural chemicals which disturb the proper functioning of agroecosystems and ecosystems coexisting with farming, is of special importance. However, due to increased labor resources, higher product prices, and the administrative burden related to meeting the guidelines and requirements of organic farming from the EU, its large-scale implementation in Poland within the current 
decade should not be expected. Yet, the further support of such farming by the new CAP is still expected. That is connected with the regulatory system that will have an impact on the development of organic farms, which is created both at the EU level and the national level, which refers especially to the amounts of payments.

Agriculture is a sector of the economy that has a key impact on the functioning of numerous ecosystems. In the EU, legal regulations and agricultural policy instruments are introduced to ensure an increase in the scale of ecosystem services generated by agriculture. In the future, it is planned to analyze the changes taking place in the structure of agricultural lands in EU countries in the context of promoting the concept of sustainable agriculture.

Author Contributions: Conceptualization, L.L. and K.M.; methodology, L.L. and K.M.; validation, L.L., M.Z., and K.M.; formal analysis, L.L.; data curation, L.L. and M.Z.; writing-original draft preparation, L.L., K.M., and M.Z.; writing-review and editing, K.M. and L.L. All authors have read and agreed to the published version of the manuscript.

Funding: This research received no external funding.

Institutional Review Board Statement: Not applicable.

Informed Consent Statement: Not applicable.

Data Availability Statement: Not applicable.

Conflicts of Interest: The authors declare no conflict of interest.

\section{References}

1. Lambin, E.F.; Turner, B.L.; Geist, H.J.; Agbola, S.B.; Angelsen, A.; Bruce, J.W.; Coomes, O.T.; Dirzo, R.; Fischer, G.; Folke, C.; et al. The causes of land-use and land-cover change: Moving beyond the myths. Glob. Environ. Chang. 2001, 11, 261-269. [CrossRef]

2. Barnosky, A.D.; Hadly, E.A.; Bascompte, J.; Berlow, E.L.; Brown, J.H.; Fortelius, M.; Getz, W.; Harte, J.; Hastings, A.; Marquet, P.; et al. Approaching a state shift in Earth's biosphere. Nature 2012, 486, 52-58. [CrossRef]

3. Foley, J.A.; DeFries, R.; Asner, G.P.; Barford, C.; Bonan, G.; Carpenter, S.R. Global Consequences of Land Use. Science 2005, 309, 570-574. [CrossRef]

4. König, W.; Sunkel, R.; Necker, U.; Wolf-Straub, R.; Ingrisch, S.; Wasner, U.; Glück, E. Alternativer und Konventionelier; Landbau: Stuttgart, Germany, 1989.

5. Baum, R. Sustainable development of agriculture and its assessment criteria. J. Agribus. Rural. Dev. 2008, 1, 5-15.

6. Kus, J. Systemy Gospodarowania w Rolnictwie. Rolnictwo Integrowane (Farming Systems in Agriculture. Integrated Agriculture); IUNG: Puławy, Poland, 1995.

7. Niewiadomski, W. Rolnictwo Jutra. In Biotyczne Środowisko Uprawne a Zagrożenie Chorobowe Roślin (Biotic Cultivation Environment and Plant Disease Risk); ART Olsztyn: Olsztyn, Poland, 1993.

8. Madry, W.; Gozdowski, D.; Roszkowska-Madra, B.; Hryniewski, R. Typologia systemów produkcji rolniczej: Koncepcja, metodologia i zastosowanie (Typology of agricultural production systems: Concept, methodology and application). Fragm. Agron. 2011, 28, 70-81.

9. Kuś, J.; Fotyma, M. Stan i perspektywy rolnictwa ekologicznego (The condition and prospects of organic farming). Fragm. Agron. 1992, 9, 75-86.

10. Kus, J.; Stalenga, J. Prospects for development of different farming systems in Poland. Biul. Inst. Hod. Aklim. Roślin 2006, 242, $15-25$.

11. Sołtysiak, U. O kryteriach w Rolnictwie Ekologicznym. In Rolnictwo Ekologiczne od Producenta do Konsumenta (Organic Farming From Producer to Consumer); Stowarzyszenie EKOLAND: Warszawa, Poland, 1995.

12. Zimny, L. Definitions and divisions of farming systems. Acta Agrophys. 2007, 10, 507-518.

13. Musial, K.; Musial, W. The Role of Deagriarisation Process in Creating Threats for the Regional Economy and Nature in Selected Conservation Areas in South-Eastern Poland. In Proceedings of the 36th IBIMA, Grenada, Spain, 4-5 November 2020; pp. 6739-6748.

14. Kus, J.; Jończyk, K. Development of organic farming in Poland. Rozwój rolnictwa ekologicznego w Polsce. J. Res. Appl. Agricult. Eng. 2009, 3, 178-182.

15. Willer, H. Organic Agriculture Worldwide: The Main Results of the FiBl-IFOAM Survey. 2009. Available online: http://www. organic-world.net/fileadmin/images/yearbook/2009-graphs (accessed on 21 February 2021).

16. Angiolini, S.; Barbosa, P.; Bektasiadou, V.; Gardner, S.; Hudson, T.; Keenleyside, C.; Kirketerp, C.H.; L'her, R.; Plaza, L.M.; Mauperon, L.; et al. EU Rural Review. A Publication from the European Network for Rural Development. Organic Farming. Available online: https:/ / enrd.ec.europa.eu/sites/default/files/publications-enrd-rr18_en.pdf (accessed on 6 June 2021).

17. Majewski, E. Wytyczne do Integrowanej Produkcji Rolnej (Guidelines for Integrated Agricultural Production); Fundacja na Rzecz Rozwoju Polskiego Rolnictwa (FDPA): Warszawa, Poland, 1995. 
18. Proost, J.; Matteson, P. Integrated farming in the Netherlands: Flirtation or solid change? Outlook Agric. 1997, 26, 87-94. [CrossRef]

19. Daily, G.G.; Postel, S.; Bawa, K.S.; Kaufman, L. Nature's Services: Societal Dependence on Natural Ecosystems. 1997. Available online: Books.google.com (accessed on 15 February 2021).

20. Costanza, R.; D’Arge, R.; De Groot, R.; Farber, S.; Grasso, M.; Hannon, B.; Limburg, K.; Naeem, S.; O’Neill, R.V.; Paruelo, J.; et al. The value of the world's ecosystem services and natural capital. Nature 1997, 387, 253-260. [CrossRef]

21. Díaz, S.; Fargione, J.; Chapin, F.D. Tilman Biodiversity loss threatens human well-being. PLoS Biol. 2006, 4, e277. [CrossRef] [PubMed]

22. Ramalho, C.; Hobbs, R. Time for a change: Dynamic urban ecology. Trends Ecol. Evol. 2012, 27, 179-188. [CrossRef] [PubMed]

23. Zari, M.P. Ecosystem Services Analysis in Response to Biodiversity Loss Caused by the Built Environment. SAPIENS 2014, 7, $1-14$.

24. Sierka, E.; Roszkowska, E.; Woźniak, G. Znaczenie Wody Dla Funkcjonowania Ekosystemów na Terenach Miejsko-Przemysłowych Aktualne Problemy Gospodarki Wodnej (Current Problems in Water Management); Ślaskie Centrum Wody: Katowice, Poland, 2018.

25. Millennium Ecosystem Assessment Ecosystems and Human Well-Being: Biodiversity Synthesis; World Resources Institute: Washington, DC, USA, 2005.

26. Braat, L.C.; De Groot, R. The ecosystem services agenda: Bridging the worlds of natural science and economics, conservation and development, and public and private policy. Ecosyst. Serv. 2012, 1, 4-15. [CrossRef]

27. Wall, D.H.; Nielsen, U.N. Biodiversity and Ecosystem Services: Is It the Same Below Ground? Educ. Knowl. $2012,3,8$.

28. Norton, B.A.; Bending, G.D.; Clark, R.; Corstanje, R.; Dunnett, N.; Evans, K.L.; Grafius, D.R.; Gravestock, E.; Grice, S.M.; Harris, J.A.; et al. Urban Meadows as an Alternative to Short Mown Grassland: Effects of Composition and Height on Biodiversity. Ecol. Appl. 2019, 29, 1095-1115. [CrossRef]

29. Nelson, E.; Mendoza, G.; Regetz, J.; Polasky, S.; Tallis, H.; Cameron, D.; Chan, K.; Daily, G.C.; Goldstein, J.; Kareiva, P.M.; et al. Modeling multiple ecosystem services, biodiversity conservation, commodity production, and tradeoffs at landscape scales. Front. Ecol. Environ. 2009, 7, 4-11. [CrossRef]

30. Wieliczko, B. Applying ecosystem services in natural resource management in agriculture. Studia Pr. WNEiZ 2016, 46, 135-144. [CrossRef]

31. Bull, J.W.; Jobstvogt, N.; Böhnke-Henrichs, A.; Mascarenhas, A.; Sitas, N.; Baulcomb, C.; Lambini, C.K.; Rawlins, M.; Baral, H.; Zähringer, J.; et al. Strengths, Weaknesses, Opportunities and Threats: A SWOT analysis of the ecosystem services framework. Ecosyst. Serv. 2016, 17, 99-111. [CrossRef]

32. Knutelski, S. Biodeversity is human welfare. Pol. J. Sustain. Dev. 2018, 22, 27-38. [CrossRef]

33. Minixhofer, P.; Stangl, R. Green Infrastructures and the Consideration of Their Soil-Related Ecosystem Services in Urban Areas-A Systematic Literature Review. Sustainability 2021, 13, 3322. [CrossRef]

34. Maes, J.; Teller, A.; Nessi, S.; Bulgheroni, C.; Konti, A.; Sinkko, T.; Tonini, D.; Pant, R. Mapping and Assessment of Ecosystems and Their Services: An EU Ecosystem Assessment; Publications Office of the European Union: Luxembourg, 2020. [CrossRef]

35. Ryszkowski, L. Strategia Ochrony Środowiska Rolniczego-Stan Obecny i Perspektywy (Agricultural Environment Protection Strategy-Current State and Prospects). In Przyrodnicze i Techniczne Problemy Ochrony i Kształtowania Środowiska Rolniczego. In Proceedings of the II Ogólnopol. Konf. Nauk, Poznań, Poland, 4-5 September 1997; pp. 159-167.

36. Wieland, E.; Marchlewski, K. Przesłanki rozwoju rolnictwa zrównoważonego w Wielkopolsce (Premises for the development of sustainable agriculture in Wielkopolska). Przegl. Komunal. 1998, 7, 6-19.

37. Główny Urząd Statystyczny, Rocznik Rolnictwa 2010, 2018 (Yearbook of Agriculture); GUS: Warszawa, Poland, 2019.

38. Kukula, K. Statystyczna Analiza Strukturalna i jej Zastosowanie w Sferze Ustug Produkcyjnych dla Rolnictwa (Statistical Structural Analysis and Its Application in the Sphere of Production Services for Agriculture); Zeszyty Naukowe AE w Krakowie, Seria specjalna: Krakow, Poland, 1989.

39. Chomatowski, S.; Sokolowski, A. Taksonomia struktur (Structural taxonomy). Przeglad Stat. 1978, 2, $217-226$.

40. Kaluga, I. Korzyści dla Rolnictwa Wynikające z Gospodarowania na Obszarach Natura 2000 (Benefits for Agriculture Resulting from Farming in Natura 2000 Areas); Ministerstwo Środowiska: Warszawa, Poland, 2009.

41. Matuszkiewicz, W. Identification of Plant Communities in Poland; PWN: Warsaw, Poland, 2002.

42. Steffen, W.; Richardson, K.; Rockström, J.; Cornell, S.E.; Fetzer, I.; Bennett, E.M.; Biggs, R.; Carpenter, S.R.; De Vries, W.; De Wit, C.A.; et al. Planetary boundaries: Guiding human development on a changing planet. Science 2015, 347. [CrossRef]

43. Komorowska, D. Comparison of ecological farms with conventional ones within area groups. Pr. Nauk. Uniw. Ekon. Wroctawiu 2011, 166, 312-322.

44. Gruszecki, T.M.; Junkuszew, A. Przeżuwacze w Czynnej Ochronie Środowiska. (Ruminants in Active Environmental Protection); Wydawnictwo Uniwersytetu Przyrodniczego w Lublinie: Lublin, Poland, 2017.

45. Antle, J.M.; Stoorvogel, J.J. Predicting the supply of ecosystem services from agriculture. Am. J. Agric. Econ. 2006, 88, 1174-1180. [CrossRef]

46. Zarzycki, K.; Trzcinska-Tacik, H.; Rozanski, W.; Szelag, Z.; Wolek, J.; Korzeniak, U. Ecological Indicator Values of Vascular Plants of Poland; Szafer Institute of Botany, Polish Aceadem of Sciences: Krakow, Poland, 2002.

47. Dzwonko, Z. Assessment of light and soil conditions in ancient and recent woodlands by Ellenberg indicator values. J. Appl. Ecol. 2001, 38, 942-951. [CrossRef] 
48. May, R.M.; Lawton, J.H.; Stork, N.E. Assessing Extinction Rates. In Extinction Rates; Lawton, J.H., May, R.M., Eds.; Oxford University Press: Oxford, UK, 1995; pp. 1-24.

49. Jenkins, C.N.; Sanders, N.J.; Andersen, A.N.; Carsten, X.A.; Brühl Cerda, X.; Ellison, A.M.; Fisher, B.L.; Fitzpatrick, M.C.; Gotelli, N.J.; Gove, A.D.; et al. Global diversity in light of climate change: The case of ants. Divers. Distrib. 2011, 17, 652-662. [CrossRef]

50. Robinson, T.P.; Thornton, P.K.; Franceschini, G.; Kruska, R.L.; Chiozza, F.; Notenbaert, A.; See, L. Global Livestock Production Systems; FAO: Rome, Italy; ILRI: Nairobi, Kenya, 2011. Available online: https://www.fao.org/docrep/014/i2414e/i2414e.pdf (accessed on 3 March 2021).

51. Bauer, S.E.; Tsigaridis, K.; Miller, R. Significant atmospheric aerosol pollution caused by world food cultivation. Geophys. Res. Lett. 2016, 43, 5394-5400. [CrossRef]

52. Dubas, A. Sustainable development in contemporary agriculture systems. Fragm. Agron. 2007, 3, 71-75.

53. Musial, K.; Walczak, J. Organic farms oriented towards animal production in the Malopolskie Voivodeship. Rocz. Nauk. Zootech. 2017, 44, 319-333.

54. Plieninger, T.; Schleyer, C.; Schaich, H.; Ohnesorge, B.; Gerdes, H.; Hernández-Morcillo, M.; Bieling, C. Mainstreaming ecosystem services through reformed European agricultural policies. Conserv. Lett. 2012, 5, 281-288. [CrossRef]

55. Pe’er, G.; Zinngrebe, Y.; Moreira, F.; Sirami, C.; Schindler, S.; Müller, R.; Bontzorlos, V.; Clough, D.; Bezák, P.; Bonn, A.; et al. A greener path for the EU Common Agricultural Policy. Science 2019, 365, 449-451. [CrossRef] [PubMed]

56. Kleijn, D.; Sutherland, W.J. How effective are European agri-environment schemes on conserving and promoting biodiversity? J. Appl. Ecol. 2003, 40, 947-970. [CrossRef]

57. Verhulst, J.; Kleijn, D.; Berendse, F. Direct and indirect effects of the most widely implemented Dutch agri-environment schemes on breeding waders. J. Appl. Ecol. 2007, 44, 70-80. [CrossRef]

58. Whittingham, M.J. Will agri-environment schemes deliver substantial biodiversity gain, and if not why not? J. Appl. Ecol. 2007, 44, 1-5. [CrossRef]

59. Van Dijk, C.E.; Zock, J.P.; Baliatsas, C.; Smit, L.A.; Borlee, F.; Spreeuwenberg, P.; Yzermans, C.J. Health conditions in rural areas with high livestock density: Analysis of seven consecutive years. Environ. Pollut. 2017, 222, 374-382. [CrossRef] [PubMed]

60. Smit, L.A.; Heederik, D. Impacts of Intensive Livestock Production on Human Health in Densely Populated Regions. GeoHealth 2017, 1, 271-296. [CrossRef]

61. Glodowska, M.; Galazka, A. Impact of Organic Farming on Natural Environment within the Concept of Sustainable Development. Wieś Rol. 2017, 2, 147-165. [CrossRef]

62. Baum, R.; Majchrzycki, D. Kierunki Rozwoju Rolnictwa w Perspektywie Przystapienia do Unii Europejskiej (Directions of Agriculture Development in the Perspective of Accession to the European Union); Wroclaw University of Economics: Wroclaw, Poland, 2000; Volume 865.

63. Nachtman, G. Ekologiczne gospodarstwa w Polsce i w Niemczech-Analiza porównawcza (Organic farms in Poland and Germany-A comparative analysis). Zag. Dor. Rol. 2008, 2, 50-60.

64. Krasowicz, S. W Polsce Powinno Dominować Rolnictwo Zrównoważone. In Przyszłość Sektora Rolno-Spożywczego i Obszarów Wiejskich (The Future of the Agri-Food Sector and Rural Areas); IUNG-PIB: Puławy, Poland, 2009; pp. 20-38.

65. Podawca, K.; Dabkowski, N. Spatial Diversification of Situation of the Organic Farming in the Polish Voivodeships in the Years 2010-2018. J. Ecol. Eng. 2020, 21, 191-200. [CrossRef]

66. Gulbicka, B. Rynek Żywności Ekologicznej. In Ekonomiczne i Społeczne Uwarunkowania Rozwoju Polskiej Gospodarki Żywnościowej po Wstapieniu Polski do Unii Europejskiej (Economic and Social Conditions for the Development of the Polish Food Economy after Poland's Accession to the European Union); IERiGŻ-PIB: Warszawa, Poland, 2007.

67. Golik, D.; Żmija, D. Organic Farming and the Prospects for Its Development in Poland in the Light of the European Union's Experience. Zesz. Nauk. Uniw. Ekon. Krakowie 2017, 1, 117-129. [CrossRef]

68. Gołaś, Z. Development of organic farming in Poland. J. Agribus. Rural. Dev. 2016, 4, 533-543. [CrossRef] 